\title{
Original
}

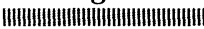

\section{Distortion of Pulse Height Spectra Due to Absorbers in the Measurement of Low-energy $\beta$-rays with a Silicon Detector}

\author{
Hisao Yamamoto, Toshiaki Abe, Toshiyuki Norimura* and Akira Katase** \\ Radioisotope Research Center, * Department of Radiation Biology and Health, \\ University of Occupational and Environmental Health, Japan \\ 1-1 Iseigaoka, Yahatanishi-ku, Kitakyushu-shi, Fukuoka Pref. 807-8555, Japan \\ ** Yohshindo Laboratory \\ 4-22-3 Miwadai, Higashi-ku, Fukuoka-shi 811-0212, Japan \\ Received May 30, 2002
}

\begin{abstract}
In measurement of $\beta$-rays from ${ }^{14} \mathrm{C}$ with a silicon semiconductor detector, pulse height spectra are observed to change by insertion of absorbers between the source and the detector. An obvious broad peak appears in the spectra by the insertion. An increase in the absorber thickness reduces the peak height, and shifts the peak position to the higher energy side in the spectra. On the other hand, the increase in the distance between the source and the absorber also reduces the peak height, but does not move the position of the peak. The absorption curve derived from these results shows its particular shape corresponding to the respective position of the absorber. Therefore, the distortion of the pulse height spectrum for low-energy $\beta$ rays depends not only on the thickness of the absorber but also on its position between the source and the detector.
\end{abstract}

Key Words : carbon-14, beta ray, spectrum distortion, absorption curve, silicon detector, absorber

\section{Introduction}

In the relative measurement of the intensity of $\beta$-emitting radioisotopes, the absolute efficiency of a detector is obtained by using a standard $\beta$-ray source of known activity. The standard sources are usually sealed with thin foils for safe and easy handling. The angular distribution and the energy spectrum of $\beta$-rays emitted from the sealed source change by scattering and absorption of $\beta$-rays passing through the foils. Information about the effects of the absorber on the emission angle and the pulse height spectrum of $\beta$-rays is, therefore, required to precisely obtain the intensity of the samples containing $\beta$-emitting radioisotopes.

In the previous measurement, we found the anisotropy of $\beta$-ray emission from the sealed source 1 ), and proposed a simple method for the calculation of the angular distribution of $\beta$-rays for a sealed standard source of $14 \mathrm{C} 2$ ),3). In addition, the effects of the anisotropy were evaluated on the determination of detection efficiency of $\beta$-ray detector ${ }^{4)}$. A method to correct these effects was also developed.

On the other hand, although the pulse height spectra of $\beta$-rays have been described in many articles 1),2),5)-11), so far as we know, the distortion of the spectrum due to the absorber was not reported except an estimation11), where the change in the spectrum of $\beta$-rays from ${ }^{14} \mathrm{C}$ was calculated only for the absorption in source itself and that in air existing between the source and the detector. Therefore, more 
systematic experiments are required to make clear the effects of absorber on the intensity calibration of $\beta$-rays.

In this work, $\beta$-rays from ${ }^{14} \mathrm{C}$ were measured with a silicon semiconductor detector, and then the distortion of the pulse height spectrum was studied by changing the thickness and the position of the absorber placed between the source and the detector. From these results, the effects of such variation on absorption curves were also studied.

\section{Experimental Method}

The measurement system was composed of a Canberra 2100A preamplifier, a Canberra 2021 spectroscopy-amplifier and an EG\&G ORTEC 7100 multichannel analyzer. The semiconductor radiation detector fabricated from a commercial silicon photodiode12),13) was used for detection of $\beta$-rays. The active area of the detector was $13.2 \mathrm{~mm}^{2}(4.1 \mathrm{~mm}$ diameter) and the depth of the depletion layer was estimated to be about $100 \mu \mathrm{m}$. The ${ }^{14} \mathrm{C}$ source of about $2 \mathrm{~mm}$ diameter was made by dropping a small quantity of aqueous solution

(containing $3 \%$ ethanol) of ${ }^{14} \mathrm{C}$ polyethylene glycol onto a Mylar (polyethylene terephthalate, $0.889 \mathrm{mg} / \mathrm{cm}^{2}$ ) foil. During the experiment, the $\beta$-ray source, the absorber (Mylar) and the detector were placed in an evacuated chamber (Canberra 7400).

The interior dimensions of the chamber were $133 \mathrm{~mm}$ in diameter and $90 \mathrm{~mm}$ in depth, and the inside surface was lined with polyethylene sheets $(0.5 \mathrm{~mm}$ thick $)$ to reduce the scattered electrons. The detector was set at the point of half depth in the chamber. Its sensitive surface was placed at $33 \mathrm{~mm}$ away from the cylindrical wall and pointed toward the center of the chamber. The source was located at distance of $26 \mathrm{~mm}$ from the detector surface on the central line of the chamber and separated by $74 \mathrm{~mm}$ from the opposite wall surface. The absorber (20 mm diameter) was set at one of the position of $1,7,13,19$ and 25 $\mathrm{mm}$ from the source. All the measurements were performed at room temperature.

Effects of the $\beta$-rays backscattered by the wall of the chamber on the counting rate were corrected by using the previous results2) obtained for three lining materials of the wall. These data showed that the counting rate increases almost linearly with the atomic number of the lining materials for various emission angles of $\beta$-rays. Relative magnitude of the corrections was $0.8 \%$ for the effective atomic number (4.75) of the lining material (polyethylene) used in this experiment.

\section{Results and Discussion}

Figure 1 shows the pulse height spectra measured for $10000 \mathrm{~s}$ for each thickness of the absorber set at a distance of $1 \mathrm{~mm}$ from the $\beta$ ray source. The channel number is nearly equal to the energy expressed in keV. For no absorber a small peak with a steep slope appears in the low-energy region, and then it becomes broader by inserting the absorber. This tendency is similar to that calculated by Borg11) for the absorption in air existing between the source and the detector. It is worth to notice that for the two absorber thicknesses of 0.427 and $0.889 \mathrm{mg} / \mathrm{cm}^{2}$ the pulse height spectra almost overlap with that for no absorber in the region of energy higher than $30 \mathrm{keV}$. This result means that the energy loss for these thin absorbers is almost negligible in this energy region, since the stopping power for electrons is small.

Figure 2 represents the variation of the 


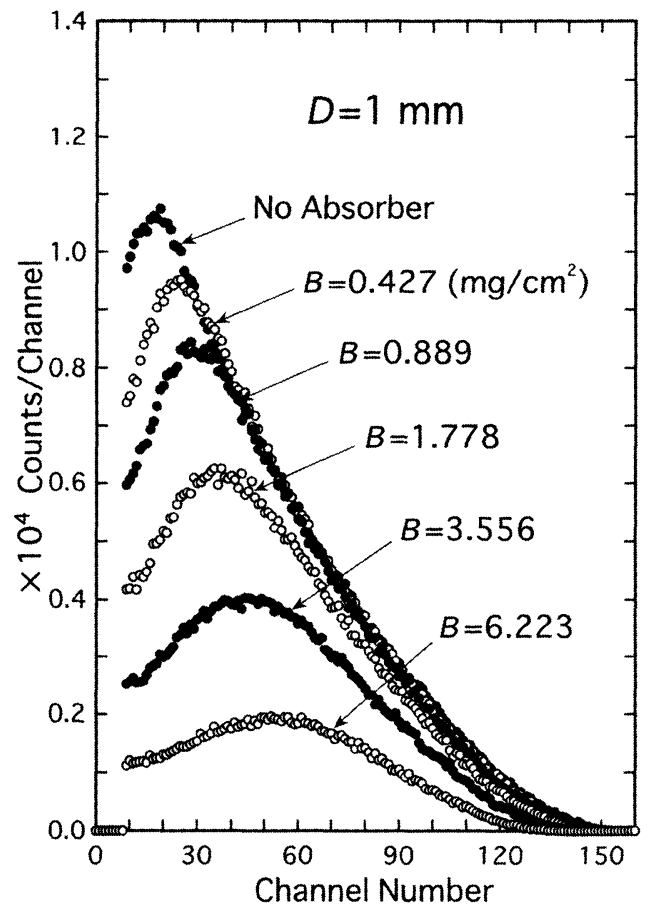

Fig. 1 Pulse height spectra measured for $10000 \mathrm{~s}$ for each thickness of the absorber set at a distance of $1 \mathrm{~mm}$ from the $\beta$-ray source of ${ }^{14} \mathrm{C}$.

peak point against the absorber thickness $B$. Open and closed circles indicate the results for the channel number $H_{\mathrm{p}}$ and the relative count $N_{\mathrm{p}}$ at the peak point, respectively. Solid and broken lines are fitted to these experimental values by applying the least squares method and expressed by the following respective formulas :

$$
H_{\mathrm{p}}=-36.4 \exp (-0.409 B)+55.1
$$

and

$$
N_{\mathrm{p}}=0.982 \exp (-0.324 B)+0.079 .(2)
$$

Thus, with increasing absorber thickness, the peak height decreases and simultaneously the peak channel is shifted to the higher energy side. This phenomenon is attributed to the fact that in the low-energy region the stopping power for electrons decreases with increasing energy ${ }^{14)}$. Electrons with lower energy are

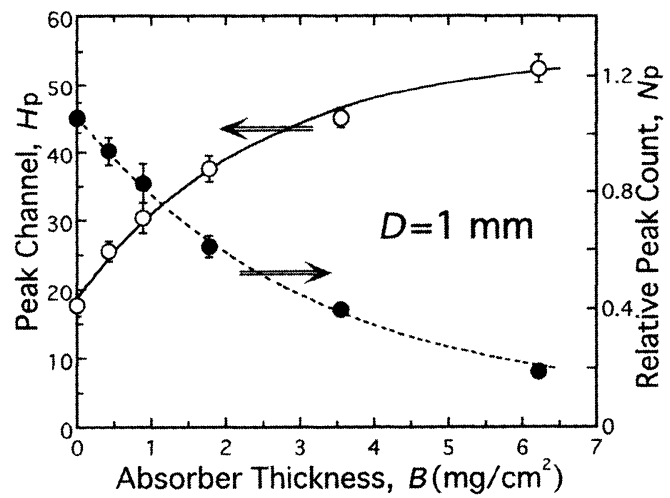

Fig. 2 Variations of the channel number (open circles) and the relative count (closed circles) at the peak point in the spectra of Fig. 1 against the absorber thickness. Solid and broken curves (expressed by Eqs. (1) and (2), respectively) are fitted to these experimental values by applying the least squares method.

more easily absorbed by increasing the thickness of absorber.

In Fig. 3 is shown the pulse height spectra measured for $10000 \mathrm{~s}$ with the absorber of $B=$ $1.778 \mathrm{mg} / \mathrm{cm}^{2}$ put at various distances from the $\beta$-ray source. The distance between the source and the detector is fixed at $26 \mathrm{~mm}$. Figure 4 represents the variations of the peak channel and the relative count at the peak point against the distance $D$ between the source and the absorber. Circles and lines have the same meaning as in Fig. 2. The solid and broken lines are expressed by the following respective equations :

$$
H_{\mathrm{p}}=0.0472 D+38.0
$$

and

$$
N_{\mathrm{p}}=0.243 \exp (-0.117 D)+0.394 .
$$

In this case, the peak channel hardly changes for the variation of the distance. On the contrary, although the peak height decreases with increasing distance, the rate of change is reduced and the shape of spectrum scarcely 


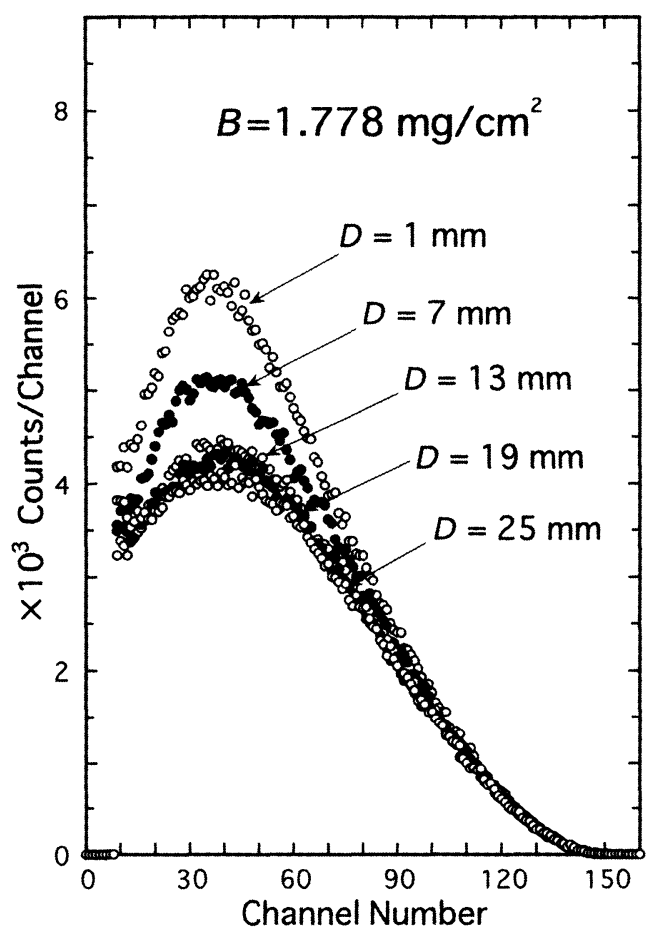

Fig. 3 Pulse height spectra measured for $10000 \mathrm{~s}$ for an absorber thickness of $1.778 \mathrm{mg} / \mathrm{cm}^{2}$ at various distances from the $\beta$-ray source of ${ }^{14} \mathrm{C}$.

varies for the distance more than $13 \mathrm{~mm}$. The qualitative explanation for this tendency is as follows. Two kinds of $\beta$-rays impinge on the detector. One of them consists of those which pass through the absorber without scattering and absorption, and hit straight on the detector. The number of these $\beta$-rays is nearly independent of the position of the absorber. Beta-rays of the other kind are those scattered in a region of the absorber and deflected to the detector. The region is around the center of the absorber. This center denotes the point at which the line connecting both centers of the source and the detector crosses the absorber surface. The number of $\beta$-rays scattered in the region decreases with the increasing distance $D$ between the source and the absorber. On

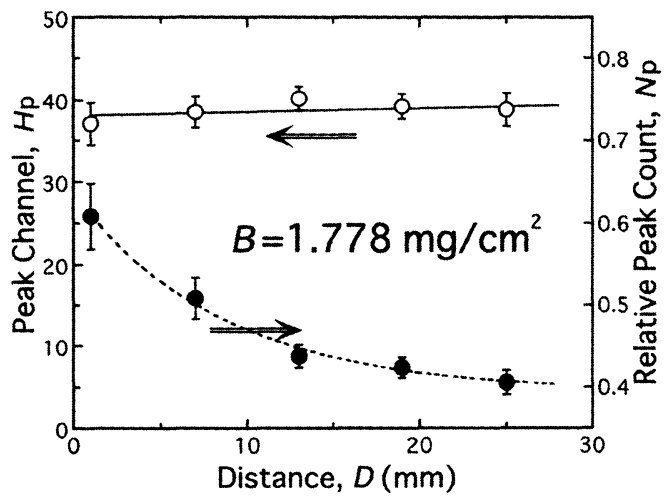

Fig. 4 Variation of the peak point in the spectra of Fig. 3 against the distance between the source and the absorber.

Circles and lines have the same meaning as in Fig. 2. Solid and broken lines are expressed by Eqs. ( 3 ) and ( 4 ), respectively.

the other hand, considering the mean free path of electrons in the absorber, forward scatterings are most probable. Then, the ratio of the number of $\beta$-rays which enter the detector, to that of scattered ones in the region dose not change appreciably with the distance $D$. From these two reasons, the number of $\beta$ rays that are scattered in the absorber and impinge on the detector is considered to decrease with the increasing $D$. For further detailed explanation the quantitative estimation is required.

From the measured pulse height spectra, absorption curves were derived for the $\beta$-rays from ${ }^{14} \mathrm{C}$. The counting rates were obtained by integrating these spectra from 10 to $160 \mathrm{keV}$. In Fig. 5 the results are illustrated for each distance $D$ of the absorber from the source. The ordinate of the figure shows the relative counting rate $R$ expressed on a logarithmic scale. Five lines represent the results calculated from the equation

$$
R=a_{1} \exp \left(b_{1} B\right)+a_{2} \exp \left(b_{2} B\right),
$$

where $a_{1}, a_{2}, b_{1}$ and $b_{2}$ are the coefficients 


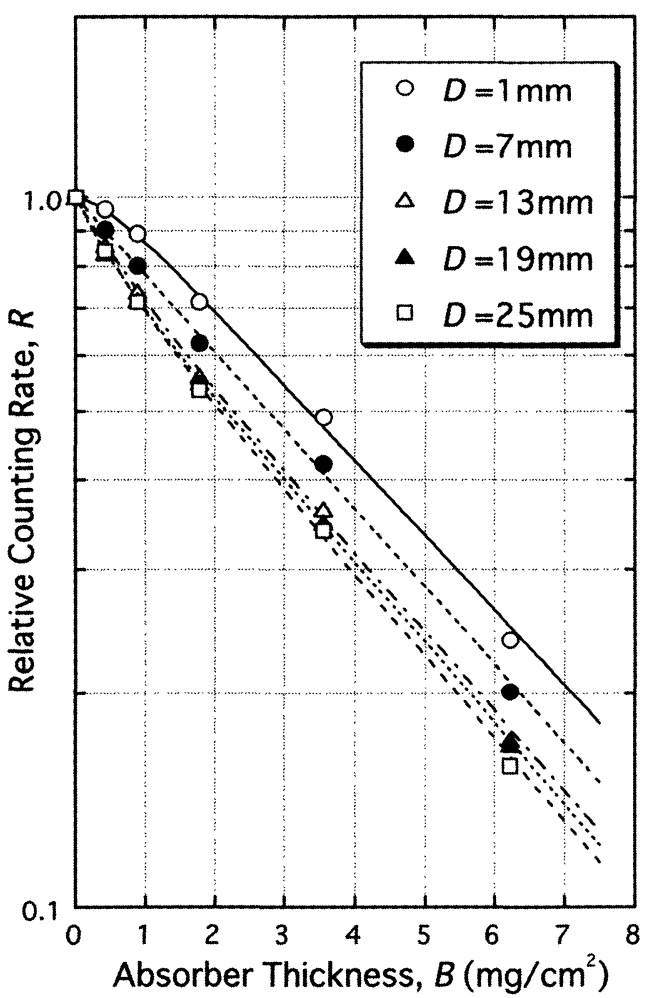

Fig. 5 Absorption curves for the $\beta$-rays from ${ }^{14} \mathrm{C}$ for five distances between the source and the absorber.

Five lines are expressed by Eq. ( 5 ). The values of the coefficients $a_{1}, a_{2}, b_{1}$ and $b_{2}$ are determined by applying the least squares method to the experimental results, and listed in Table 1. determined by applying the least squares method to the experimental results, and their values are listed in Table1. For $D=1 \mathrm{~mm}$ the line is convex upward. It becomes almost linear for $D=7 \mathrm{~mm}$, and is converted into a downward convex curve for the values of $D$ longer than 7 $\mathrm{mm}$. Moreover, when $D$ is longer than $13 \mathrm{~mm}$, the curves nearly overlap with one another. This overlap corresponds to that of the pulse height spectra shown in Fig. 3.

\section{Conclusions}

When the relatively thin absorber is inserted between the source of the $\beta$-rays and the detector, the obvious peak appears in the pulse height spectrum. With increasing absorber thickness, the height of peak is reduced, and simultaneously its position is shifted to the higher energy side. On the other hand, with increasing absorber distance from the source, the height of peak lessens, but its position does not change.

While the absorber is placed near the source, the absorption curve, whose ordinate is expressed on a logarithmic scale, is convex upward, and can not be expressed by a simple exponential function. Moving it away from the

Table 1 Coefficients in Eq. (5) for the absorption curves determined by applying the least squares method to the experimental results

\begin{tabular}{ccccc}
\hline$D(\mathrm{~mm})$ & $a_{1}$ & $a_{2}$ & $b_{1}\left(\mathrm{~cm}^{2} / \mathrm{mg}\right)$ & $b_{2}\left(\mathrm{~cm}^{2} / \mathrm{mg}\right)$ \\
\hline 1 & $1.12 \pm 0.06$ & $-0.118 \pm 0.057$ & $-0.242 \pm 0.016$ & $-2.3 \pm 1.7$ \\
7 & $1.00 \pm 0.01$ & - & $-0.253 \pm 0.006$ & - \\
13 & $0.882 \pm 0.073$ & $0.119 \pm 0.072$ & $-0.257 \pm 0.020$ & $-1.38 \pm 0.86$ \\
19 & $0.875 \pm 0.022$ & $0.125 \pm 0.022$ & $-0.262 \pm 0.008$ & $-1.95 \pm 0.47$ \\
25 & $0.852 \pm 0.052$ & $0.149 \pm 0.051$ & $-0.266 \pm 0.015$ & $-1.47 \pm 0.55$ \\
\hline
\end{tabular}


source, downward convex curves are observed. One should also take notice that the distortion of the pulse height spectrum for low-energy $\beta$ rays depends not only on the thickness of the absorber but also on its position between the source and the detector.

\section{References}

1) Yamamoto, H., Hatakeyama, S., Norimura, T., Tsuchiya, T. and Katase, A.: Anisotropic $\beta$-ray emission from a standard source due to selfabsorption, Nucl. Instrum. Meth., B53, 178-183 (1991)

2) Yamamoto, H., Norimura, T. and Katase, A.: Angular distributions of low-energy $\beta$-rays emitted from a sealed source, Appl. Radiat. Isot., 45, 317-323(1994)

3) Yamamoto, H., Norimura, T. and Katase, A.: Estimation of angular distributions of the lowenergy $\beta$-ray emission from a sealed source, Radioisotopes, 44, 771-775(1995)

4) Yamamoto, H., Norimura, T. and Katase, A.: Effects of the anisotropy of $\beta$-ray emission from a sealed source on the detection efficiency, Nucl. Instrum. Meth., A396, 418-422 (1997)

5) Bom, V. R.: Data analysis for a semiconductor beta ray spectrometer, Nucl. Instrum. Meth., 220 . 479-488 (1984)

6) Rathbun, L.A.: Factors involved in the interpretation of beta spectra, PNL-SA-15004,U. S. Department of Energy, Washington, D. C. (1987)
7) Ouseph, P. J., Davis, C. L. and O'Bryan, M. R.: Shape of $\beta$ spectrum obtained with thin detectors, Rev. Sci. Instrum., 60, 962-963(1989)

8) Wampler, W. R. and Doyle, B. L.: Low-energy beta spectroscopy using pin diodes to monitor tritium surface contamination, Nucl. Instrum. Meth., A349, 473-480 (1994)

9) Farrell, R., Vanderpuye, K., Cirignano, L., Squillante, M.R. and Entine, G.: Radiation detection performance of very high gain avalanche photodiodes, Nucl. Instrum. Meth., A353, 176-179 (1994)

10) Pochet, T., Ilie, A., Brambilla, A. and Equer, B.: Sensitivity measurements of thick amorphoussilicon p-i-n nuclear detectors, IEEE Trans. Nucl. Sci., 43, 1452-1457 (1996)

11) Borg, J.: Monte Carlo calculations and measurements of spectra from a C-14 source, Riso-R-893(EN), Riso National Laboratory, Roskilde, Denmark (1996)

12) Yamamoto, H., Hatakeyama, S., Norimura, T. and Tsuchiya, T.: A radiation detector fabricated from a silicon photodiode, Radioisotopes, 33, 864-866 (1984)

13) Yamamoto, H., Hatakeyama, S., Norimura, T. and Tsuchiya, T.: Low-energy nuclear radiation detection with a silicon photodiode, Nucl. Instrum. Meth., A281, 128-132 (1989)

14) ICRU : "Stopping Powers for Electrons and Positrons”, ICRU Report-37, p. 180, International Commission on Radiation Units and Measurements, Bethesda (1984) 
要旨

\title{
低エネルギー $\beta$ 線に対するシリコン検出器からの 波高スペクトルの吸収体による变形
}

\author{
山本久夫，阿部利明，法村俊之*，片瀬 涁** \\ 産業医科大学アイソトープ研究センター, * 同大学医学部放射線衛生学教室 \\ 807-8555 福岡県北九州市八幡西区医生ヶ丘 $1-1$ \\ ** 養真堂研究室 \\ 811-0212 福岡市東区美和台 4-22-3
}

\begin{abstract}
シリコン半導体検出器を用いて ${ }^{14} \mathrm{C}$ からの $\beta$ 線を測定する際に, 線源と検出器との間に吸収体が ある場合に，波高スペクトルがどのように変化するかを調べた。吸収体を扦入すると，波高スペク トルには幅広い明確なピークが生じた。吸収体の厚さを増加させるとピークの高さが隇少するとと もに, ピークの位置は高エネルギー側に移動した。一方, 吸収体が線源から離れるに従って, ピー クの高さは滅少するが, その位置には変化はなかった。また, 得られたスペクトルから $\beta$ 線の吸 収曲線を求めたところ, 単純な指数関数曲線ではなく, 吸収体の位置によってそれぞれ特徵のある 曲線となった。以上の結果から, 低エネルギー $\beta$ 線の波高スペクトルは, 吸収体の厚さによって 変化するだけでなく, 吸収体が線源と検出器との間のどの位置にあるかによって違ってくることが わかった。
\end{abstract}

